\title{
ERRATUM
}

\section{The International Criminal Court: A Commentary on the Rome Statute. 2nd edition. By William A. Schabas. Oxford, UK: Oxford University Press, 2016. Pp. xci, 1,589. ISBN 978-0-19-873977-7. US\$330.00. - ERRATUM}

\author{
Roy L. StURgEON
}

https://doi.org/10.1017/jli.2017.46, Published by Cambridge University Press, 24 November 2017.

In the original publication of this book review there were several typographical errors introduced in the typesetting process, for which the publisher apologises. Please find these errors and correct sentences listed below.

Page 264:

The year before saw publication of The Law and Practice of the International Criminal Court, a hefty collection of 5050 separately authored essays that join analyses with reform proposals.

Should be read as:

The year before saw publication of The Law and Practice of the International Criminal Court, a hefty collection of 50 separately authored essays that join analyses with reform proposals.

Co-edited by the late, great international criminal law scholar Otto Triffterer, it has comments by more than 8080 drafters and scholars worldwide on every article and paragraph and sometimes even interprets single words.

Should be read as:

Co-edited by the late, great international criminal law scholar Otto Triffterer, it has comments by more than 80 drafters and scholars worldwide on every article and paragraph and sometimes even interprets single words.

He opens with a relatively brief (2727-page), scholarly but clear overview of international criminal law's evolution from 1919 to the entry into force of the Rome Statute in 2002.

Should be read as:

He opens with a relatively brief (27-page), scholarly but clear overview of international criminal law's evolution from 1919 to the entry into force of the Rome Statute in 2002.

Most run 10-1510 to 15 pages. The longest, Article 8 (war crimes), runs 8787 pages: somewhere between a journal article and a monograph.

Should be read as:

Most run 10-15 pages. The longest, Article 8 (war crimes), runs 87 pages: somewhere between a journal article and a monograph. 
Page 265:

Also, reflecting increased ICC docket activity in the intervening five-and-a-half years, the list of ICC cases in the second edition's Table of Cases is 2121 pages longer.

Should be read as:

Also, reflecting increased ICC docket activity in the intervening five-and-a-half years, the list of ICC cases in the second edition's Table of Cases is 21 pages longer.

\section{REFERENCE}

Sturgeon, R. (2017). The International Criminal Court: A Commentary on the Rome Statute. 2nd edition. By William A. Schabas. Oxford, UK: Oxford University Press, 2016. Pp. xci, 1,589. ISBN 978-0-19-873977-7. US\$330.00. International Journal of Legal Information, 45(3), 263-265. doi:10.1017/jli.2017.46 